\title{
Ganti Kerugian dan Rehabilitasi Bentuk Perlindungan Terhadap Korban Tindak Pidana dan Korban Proses Penegakan Hukum di Indonesia
}

\author{
Haeranah \\ Dosen Fakultas Hukum Universitas Hasanuddin, Email: haeranahnurdin1966@gmail.com
}

\author{
Amriyanto \\ Dosen Fakultas Hukum Universitas Khairun, Email: amriyantounkhair@gmail.com
}

\begin{abstract}
This research and analysis is interesting because the author divides victims into 2 (two) forms, namely, general victims of law enforcement processes and crimes. Compensation and rehabilitation are the rights of victims that the state must enforce through legal means. This research is a normative research through a conceptual and statutory approach and the legal materials obtained are analyzed in an explanatory-deductive. The results indicate that the normative aspects of the balance of regulations related to compensation and rehabilitation for victims of the law enforcement process and victims of crimes in the Indonesian judicial system are still partial, so that its realization still requires criminal procedural law, law civil procedural or a combination of the two, as well as through state administrative law facilities, especially rehabilitation. We note several shortcomings and weaknesses in the use of legal means in this document. the form of compensation for the victim is in cash, while rehabilitation is in the form of restoring the good name, dignity and respect. The mechanisms and procedures for enforcing compensation and rehabilitation for victims still need to be simplified in order to realize the rights of victims of crime and victims of a balanced law enforcement process in the future.
\end{abstract}

Keyword: Compensation; Rehabilitation; Victims

\section{PENDAHULUAN}

Hukum acara pidana Indonesia masih mengalami persoalan mendasar terkait keseimbangan perlindungan hukum terhadap korban tindak pidana dengan pelaku tindak pidana, mengingat korban tindak pidana dianggap sudah diwakili oleh aparat penegak hukum untuk memperjuangkan kepentingan hukum mereka, namun belum optimal $^{1}$. Kehadiran korban tindak pidana hanya sebatas saksi korban yang dapat memberikan keterangan kepada aparat penegak hukum terkait dengan peristiwa pidana yang menimpahnya, namun ternyata hal tersebut juga terjadi di negara lain Blonde ${ }^{2}$ mengakui secara tradisional sistem peradilan pidana di Amerika lebih banyak mengakui

\footnotetext{
${ }^{1}$ Hasmiah Hamid, 2016, Perlindungan Hukum Terhadap Korban Penganiayaan Dalam Penanganan Tindak Pidana Di Indonesia, Ecosystem, Vol. 16 No. 2 (Mei -Agustus 2016), hlm. 287

2 Erin C. Blondel, 2008, Victims' Rights in An Adversary System, Duke Law Journal, Vol. 58, No. 2 (2008), hlm. 237-274.
} 
hak-hak terdakwa daripada korban. Francis D. Boateng dan Gassan Abess ${ }^{3}$ bahwa korban masih dianggap sebagai individu yang terlupakan dalam sistem peradilan, terutama menyangkut hak-haknya dan hal ini dialami sebagian besar negara karena tidak memiliki mekanisme yang efektif dalam mengimplementasikan regulasi dalam melindungi hak-hak korban.

Aspek normatif hukum acara pidana Indonesia telah memberikan perhatian perlindungan tersangka, terdakwa dan terpidana, namun realitasnya masih dijumpai tindakan penegak hukum yang mencederai hukum dan keadilan, seperti salah tangkap ${ }^{4}$. Kejadian tersebut tidak hanya terjadi di Indonesia, pengakuan korban di Ghana mereka sering kembali menjadi korban petugas Criminal Justice System (aparat penegak hukum) tidak memperlakukan mereka secara bermartabat ${ }^{5}$.

Salah satu bentuk perlindungan hukum terhadap korban tersebut di atas ganti kerugian dan rehabilitasi. Artikel ini menarik karena kajian dilakukan secara komperhensif terkait konsep ganti kerugian dan rehabilitasi sebagai bentuk perlindungan terhadap korban proses penegakan hukum dan korban tindak pidana dalam hukum acara pidana di Indonesia. Kajian dan analisis ini menjadi penting karena penulis mencoba melihat konsep dan eksistensi ganti kerugian dan rehabilitasi dalam tataran keseimbangan perlindungan terhadap tersangka, terdakwa dan terpidana dengan perlindungan terhadap korban tindak pidana.

\section{METODE PENELITIAN}

Penelitian ini menggunakan tipe penelitian normatif dengan pendekatan konseptual dan peraturan perundang-udangan. Bahan hukum yang digunakan berupa bahan hukum primer dan bahan hukum sekunder, dengan menggunakan metode deduktif dengan teknis analisis eksplanatif yang diharapkan dapat menjawab permasalahan yang menjadi fokus kajian dan analisis.

\section{ANALISIS}

\section{Ganti Kerugian dan Rehabilitasi Terhadap Korban Akibat Kekeliruan/Kesalahan Proses Penegakan Hukum oleh Aparat Penegak Hukum.}

Eksistensi ganti kerugian dan rehabilitasi dikenal melalui peraturan perundangundangan dikenal sejak berlakunya UU No. 14 Tahun 1970 tentang KetentuanKetentuan Pokok Kekuasaan Kehakiman (diganti melalui UU No. 48 Tahun 2009 tentang Kekuasaan Kehakiman), namun ganti kerugian dalam UU tersebut diletakkan sebagai hak seorang yang ditangkap, ditahan, dituntut atau diadili tanpa berdasarkan undang-undang atau karena kekeliruan mengenai orangnya atau hukum yang

\footnotetext{
${ }^{3}$ Francis D. Boateng dan Gassan Abess, 2017, Victims' Role in The Criminal Justice System: A Statutory Analysis of Victims' Rights in U.S., International Journal of Police Science \& Management, XX (X), hlm. 1.

${ }^{4}$ Syarif Abdul Rohma dan Umi Rozah, 2020, Kebijakan Kriminal Mengenai Pemberian Ganti Kerugian Terhadap Korban Salah Tangkap, Jurnal Pembangunan Hukum Indonesia, Vol. 2 No. 1, hlm. 117.

${ }^{5}$ Kwadwo Ofori-Dua dan Nachinaab John Onzaberigu serta Richard Kofi Nimako, 2019, Victims, the Forgotten Party in the Criminal Justices System: The Perception and Experiences of Crime Victims in Kumasi Metropolis in Ghana, Journal of Victimology and Victim Justice, Vol. 2 No. 2 (2019), hlm. 109.
} 
diterapkan ${ }^{6}$. Pengaturan terkait dengan ganti kerugian dan rehabilitasi tersebut sedikit membingungkan karena pelaksanaan dan tata cara menuntut hak tersebut belum diatur, padahal UU tersebut memberikan dasar legitimasi (atributif delegated legislatori) kepada pemerintah untuk membuat UU terkait dengan tata cara penuntutan dan pembebanan ganti kerugian dan rehabilitasi.

Sekitar 11 tahun kemudian baru berlaku UU No. 8 Tahun 1981 tentang Hukum Acara Pidana (KUHAP) yang mengatur lebih detail terkait dengan ganti kerugian dan rehabilitasi, khususnya melalui PP terkait pedoman pelaksanaan KUHAP. Ketentuan hukum acara pidana yang berlaku sebelum lahirnya KUHAP adalah HIR, namun tidak mengatur terkait dengan ganti kerugian dan rehabilitasi. KUHAP meletakkan ganti kerugian dan rehabilitasi tersebut sebagai hak yang diberikan kepada seorang tersangka, terdakwa dan terpidana yang menurut Martiman Prodjohamidjojo ${ }^{7}$ sebagai perwujudan dari perlindungan hak asasi. Penulis sependapat dengan padangan tersebut yang meletakkan ganti kerugian dan rehabilitasi sebagai perwujudan dari perlindungan hak asasi manusia, karena sesuai dengan UU HAM tersebut yang menjadi HAM adalah yang termasuk kategori HAM adalah hak dianggap tidak bersalah karena ditangkap, ditahan, dan dituntut karena disangka melakukan sesuatu tindak pidana ${ }^{8}$. Implikasi yang ditimbulkan akibat pelanggaran hak asasi manusia tersebut di atas melahirkan ganti kerugian dan rehabilitasi terhadap seorang tersangka, terdakwa dan terpidana.

\section{a. Subjek dan Objek Ganti Kerugian dan Rehabilitasi}

Ganti kerugian dan rehabilitasi terhadap korban akibat kekeliruan/kesalahan atas proses penanganan perkara pidana oleh aparat penegak hukum dalam pelaksanaan penegakan hukum diatur dalam KUHAP sejalan dengan pengaturan terkait ganti kerugian dan rehabilitasi dalam undang-undang kekuasaan kehakiman. Wujud ganti kerugian dalam hukum acara pidana berupa imbalan sejumlah uang dan wujud rehabilitasi dalam bentuk pemulihan nama baik serta kehormatan ${ }^{9}$.

Subjek ganti kerugian dan rehabilitasi akibat kekeliruan/kesalahan tindakan aparat penegak hukum pada proses penanganan perkara pidana dalam hukum acara pidana adalah tersangka atau ahli warisnya, terdakwa atau ahli warisnya dan terpidana atau ahli warisnya. Selain itu subjek ganti kerugian juga terhadap pihak lain atau pihak ketiga yang dirugikan akibat tindakan penggeledahan dan/atau penyitaan yang dilakukan oleh aparat penegak hukum dalam penanganan tindak pidana.

Objek ganti kerugian dan rehabilitasi atas tindakan kekeliruan oleh aparat penegak hukum dalam melaksanakan penegakan hukum adalah suatu tindakan atau perbuatan yang dilakukan oleh aparat penegak hukum dalam melakukan penahanan, penangkapan, penuntutan dan mengadili tanpa alasan yang berdasarkan undang-undang atau karena kekeliruan mengenai orangnya atau hukum.

Merujuk pada uraian di atas, maka perbuatan-perbuatan yang mendasari subjek ganti kerugian dan rehabilitasi tersebut dapat menuntut hak atas ganti kerugian dan pemulihan nama baik serta kehirmatan adalah sebagai berikut:

\footnotetext{
${ }^{6}$ Pasal 9 UU No. 14/1970 tentang Ketentuan-Ketentuan Pokok Kekuasaan Kehakiman, Jo Pasal 9 ayat (1) UU No. 48/2009 tentang Kekuasaan Kehakiman

7 Martiman Prodjohamidjojo, 1989, Pembahasan Hukum Acara Pidana dalam Teori dan Praktek, Pradnya Paramita, Jakarta, hlm. 80

${ }^{8}$ Pasal 18 ayat UU No. 39 Tahun 1999 tentang HAM

${ }^{9}$ Pasal 1 angka 22 KUHAP dan Pasal 9 ayat (1) UU No. 48/2009 Kekuasaan Kehakiman.
} 


\section{1) Tersangka atau Ahli Warisnya}

Terhadap tersangka dapat mengajukan tuntutan ganti kerugian dan rehabilitasi atas perbuatan:

a) Ditangkap, ditahan, atau dikenakan tindakan lain tanpa alasan yang berdasarkan undang-undang atau keliru mengenai orangnya ${ }^{10}$. Penangkapan dan penahanan harus didasarkan pada 2 bukti permulaan yang cukup ${ }^{11}$.

b) Penangkapan dilakukan dengan sewenang-wenang, dengan mempertimbangkan keseimbangan antara tindakan yang dilakukan dengan bobot ancaman, dan menghargai/menghormati hak-hak seseorang yang ditangkap.

c) Penangkapan dilakukan tanpa surat perintah penangkapan, kecuali dalam hal tertangkap tangan melakukan tindak pidana.

d) Akibat Penangkapan, penahanan, penggeledahan atau penyitaan yang telah dilakukan oleh aparatur penegak hukum, namun perkaranya tidak diajukan ke pengadilan.

e) Akibat dilakukan penghentian penyidikan perkara atau penghentian penuntutan dimana tersangka telah dilakukan upaya paksa.

\section{2) Terdakwa atau Ahli Warisnya}

Terhadap terdakwa dapat mengajukan tuntutan ganti kerugian dan rehabilitasi terhadap perbuatan:

a) Ditahan, dituntut, dan diadili, atau dikenakan tindakan lain tanpa alasan yang berdasarkan undang-undang atau keliru mengenai orangnya. ${ }^{12}$

b) Terdakwa yang diputus bebas atau lepas dari segala tuntutan hukum.

\section{3) Terpidana atau Ahli Warisnya}

Terhadap terpidana dapat mengajukan tuntutan ganti kerugian dan rehabilitasi terhadap perbuatan:

a) Diuntut dan diadili atau dikenakan tindakan lain tanpa alasan yang berdasarkan undang-undang atau keliru mengenai orangnya. ${ }^{13}$

b) Terpidana dalam proses pemeriksaan ia pernah ditahan melebihi dari masa penahanan yang ditentukan oleh undang-undang, maka terpidana dapat menuntut kerugian atas kelebihan masa penahanan yang dijalaninya.

c) Terpidana yang menjalani masa lamanya pidana yang dijatuhkan lebih singkat dari masa penahanan yang pernah dijalani, maka terpidana berhak menuntut ganti kerugian atas kelebihan masa menjalani penahanan dengan lamanya pidana yang dijatuhkan.

d) Terpidana pada saat proses pemeriksaan dilakukan penahanan, namun dinyatakan terbukti atas pasal yang tidak dapat ditahan, maka ia berhak mengajukan tuntutan ganti kerugian dan rehabilitasi.

\footnotetext{
${ }^{10}$ Adami Chazawi, 2010, Lembaga Peninjauan Kembali (PK) Perkara Pidana, Sinar Grafika, Jakarta, hlm. 123

${ }^{11}$ Putusan Mahkamah Konstitusi Nomor 21/PUU-XII/2014.

12 Adami Chazawi, ibid

${ }^{13}$ Adami Chazawi, ibid.
} 
Merujuk pada uraian tersebut di atas, maka secara umum dapat dibagi dalam 3 jenis, yakni:

a) karena ditangkap, ditahan, dituntut dan diadili atau dikenakan tindakan lain, tanpa alasan yang berdasarkan undang-undang.

b) penangkapan atau penahanan serta tindakan lain tanpa alasan yang berdasarkan undang-undang yang perkaranya tidak diajukan ke pengadilan negeri.

c) terhadap putusan bebas atau lepas dari segala tuntutan hukum yang mana terhadap tersangka atau terdakwa dilakukan tindakan upaya paksa, menuntut atau mengadili tanpa alasan yang didasarkan pada undang-undang.

Berkaitan dengan uraian di atas, maka menurut penulis bentuk perbuatan atau peristiwa dapat dilihat dari 2 hal yakni: pertama terkait dengan prosedur pelaksanaan upaya paksa yang tidak didasarkan pada ketentuan peraturan perundang-undangan, seperti disebutkan pada huruf a dan huruf $\mathrm{b}$ dan kedua terkait dengan mengandung makna bukan pada prosedur, namun terkait dengan sukjek yang dikenai upaya paksa, seperti dikemukakan pada huruf c. Alasan kedua tersebut bisa jadi prosedur pengenaan upaya paksa sudah benar, namun terjadi kekeliruan pada orang yang dikenakan upaya paksa.

Selain hak rehabilitasi sebagaimana diuraikan di atas terdapat pula hak rehabilitasi yang tercantum dalam konstitusi Indonesia, dimana pemberian rehabilitasi tersebut merupakan kewenangan presiden selaku kepala negara. Pemberian rehabilitasi oleh presiden dilakukan dengan terlebih dahulu mendapatkan pertimbangan dari Mahkamah Agung. Rehabilitasi berbeda dengan grasi yang merupakan kewenangan presiden, penulis tidak menemukan undang-undang khusus terkait dengan rehabilitasi, lain halnya dengan grasi yang telah diatur melalui undang-undang tersendiri. Menurut penulis perbedaan mendasar antara rehabilitasi dengan grasi adalah rehabilitasi oleh presiden diberikan dalam keadaan tertentu kepada bekas narapidana sedangkan grasi diberikan kepada narapidana.

\section{b. Mekanisme Permohonan Ganti Kerugian dan Rehabilitasi Korban Proses Penegakan Hukum}

Mekanisme permohonan ganti kerugian dan rehabilitasi oleh korban akibat kekeliruan/kesalahan aparat penegak hukum dalam tindakan penegakan hukum dari 2 (dua) jalur yakni: jalur hukum acara pidana dan jalur hukum acara perdata serta khusus hak rehabilitasi yang diatur dalam konstitusi diajukan melalui jalur hukum administrasi negara kepada presiden.

\section{1) Jalur Hukum Acara Pidana}

Merujuk pada uraian sebelumnya terkait dengan perbuatan atau peristiwa yang dapat dijadikan dasar bagi korban proses penanganan perkara pidana untuk mengajukan tuntutan ganti kerugian, maka berikut ini dijelaskan terkait dengan mekanisme pengajuan tuntutan ganti kerugian, yakni:

1) Tuntutan ganti kerugian yang dimohonkan bersamaan dengan permohonan praperadilan.

Terhadap tuntutan ganti kerugian yang diajukan bersamaan dengan permohonan praperadilan dilakukan atas tindakan aparat penegak hukum atas kekeliruan/kesalahan dalam hal penangkapan atau penahanan serta tindakan penggeledahan atau penyitaan. Tata cara dan mekanisme 
penyelesaian permohonan ganti kerugian tersebut diperiksa dan diputus berdasarkan mekanisme praperadilan.

2) Tuntutan ganti kerugian yang diputus bersama dengan putusan akhir.

Terhadap terdakwa yang diputus bebas atau lepas dari segala tuntutan hukum, namun sebelumnya telah dilakukan tindakan upaya paksa, pada saat pembelaan terdakwa di depan sidang pengadilan mengajukan tuntutan ganti kerugian, maka oleh hakim pengadilan yang memutus perkara tersebut dapat menjatuhkan putusan ganti kerugian.

3) Tuntutan ganti kerugian diajukan tersendiri.

Apabila tuntutan ganti kerugian sebagaimana diuraikan sebelumnya tidak diajukan bersamaan dengan permohonan praperadilan atau tidak diputus oleh hakim pengadilan bersamaan dengan putusan terhadap pokok perkara, maka dapat diajukan tersendiri tuntutan ganti kerugian kepada pengadilan negeri yang memeriksa dan memutus perkara sebelumnya. Terhadap putusan bebas atau lepas dari segala tuntutan hukum yang berkekuatan hukum tetap, maka paling lama 3 bulan sejak petikan atau salinan putusan pengadilan tersebut diterima dapat mengajukan tuntutan ganti kerugian. Selain itu terhadap penghentian penyidikan atau penuntutan perkara atas perintah putusan praperadilan, maka tuntutan ganti kerugian dapat diajukan paling lama 3 bulan sejak penetapan praperadilan. Mekanisme pemeriksaan tuntutan ganti kerugian tersebut didasarkan pada mekanisme pemeriksaan dalam sidang praperadilan. Hakim yang memeriksa tuntutan ganti kerugian dalam hal ini sedapat mungkin adalah hakim yang sama yang mengadili perkara pidananya.

Jumlah ganti kerugian yang dapat dituntut oleh tersangka, terdakwa atau terpidana didasarkan pada pertimbangan akibat yang ditimbulkan dari tindakan upaya paksa tersebut, jumlahnya paling sedikit Rp. 500.000 (lima ratus ribu rupiah) dan paling banyak Rp. 100.000.000 (seratus juta rupiah). Apabila tindakan upaya paksa tersebut mengakibatkan luka berat atau cacat, sehingga tidak dapat melakukan pekerjaan, maka tuntutan ganti kerugian paling sedikit Rp. 25.000.000 (dua puluh lima juta rupiah) dan paling banyak Rp. 300.000 .000 (tiga ratus juta rupiah), namun apabila tindakan upaya paksa tersebut megakibatkan kematian, maka tuntutan ganti kerugian paling sedikit Rp. 50.000.000 (lima puluh juta rupiah) dan paling banyak Rp. 600.000.000 (enam ratus juta rupiah) ${ }^{14}$.

Petikan putusan atau penetapan ganti kerugian diberikan kepada pemohon paling lama 3 hari setelah putusan diucapkan dan diberikan juga kepada penuntut umum, penyidik dan Menteri keuangan. Pembayaran ganti kerugian dilakukan oleh Menteri keuangan. Pembayaran ganti kerugian dilakukan oleh Menteri keuangan paling lama 14 hari kerja sejak permohonan ganti kerugian diterima oleh Menteri keuangan.

Menurut penulis terdapat persoalan mendasar terkait dengan mekanisme permohonan ganti kerugian sebagaimana diuraikan di atas, karena tidak ada batasan waktu pembayaran ganti kerugian diterima oleh pemohon sejak putusan atau penetapan ganti kerugian tersebut dibacakan. Penulis memahami betul ribetnya mekanisme dan prosedur

\footnotetext{
${ }^{14}$ Pasal 9 ayat (1) s/d ayat (3) PP No. 92/2015 tentang Perubahan Kedua atas PP No. 27/1983 tentang Pelaksanaan KUHAP
} 
pengeluaran keuangan negara, apabila permohonan pembayaran ganti kerugian tersebut disampaikan kepada Menteri kuangan.

Apabila penulis memperhatikan tata cara pembayaran ganti kerugian sebagaimana dicantumkan dalam Surat Keputusan (SK) Menteri Keuangan Nomor. 983/KMK.01/1983 tersebut, maka menurut penulis SK tersebut sudah tidak relevan dan seharusnya dilakukan perubahan, pandangan yang sama juga dikemukakan oleh Heri Purwanto ${ }^{15}$.

Permohonan pembayaran ganti kerugian sesuai dengan SK tersebut dilakukan oleh Ketua Pengadilan Negeri, yang mana harus diawali dengan Surat keputusan Otorisasi (SKO) yang dikeluarkan oleh menteri keuangan cq. Direktorat Jenderal Anggaran yang dapat disampaikan per-triwulan atau setiap kali diperlukan. SKO dan petikan putusan/penetapan pengadilan tersebut serta surat permohonan pembayaran dari yang berhak maupun Surat Perintah Pembayaran (SPP) dari ketua pengadilan negeri menjadi dasar diterbitkannya Surat Perintah Membayar (SPM) oleh kantor perbendaharaan negara. Ribetnya mekanisme yang harus dilalui oleh korban akibat tindakan kekeliruan/kesalahan oleh aparat penegak hukum untuk mendapatkan ganti kerugian.

\section{2) Jalur Hukum Acara Perdata}

Selanjutnya penulis menguraikan permohonan ganti kerugian melalui jalur hukum hukum perdata oleh korban akibat kekeliruan/kesalahan oleh aparat penegak hukum dalam tindakan penegakan hukum.

Banyak pandangan yang menyatakan bahwa kekeliruan/kesalahan dalam proses penegakan hukum oleh aparat penegak hukum dapat diajukan gugatan ganti kerugian melalui sarana hukum perdata. Pasal $1365 \mathrm{BW}^{16}$ yang menjadi dasar gugatannya, dimana ketentuan tersebut mengatur terkait dengan perbuatan melanggar hukum. Menurut penulis memang ketentuan Pasal 1365 BW tersebut tidak ada pembatasannya, sehingga semua perbuatan yang dipandang melanggar hukum yang menyebabkan kerugian bagi pihak lainnya dapat mengajukan gugatan ganti kerugian.

Dinamika tersebut juga dirasakan oleh aparat penegak hukum dalam menjalankan tugas dan tanggungjawabnya dalam melakukan tindakan penagakan hukum, oleh karena itu Mahkamah Agung mengeluarkan SEMA No. 9 Tahun 1976 yang memcoba memberikan pembatasan terkait dengan gugatan perdata terhadap hakim dalam menjalankan tugas dan kewajibannya dalam memeriksa, mengadili dan memutus perkara.

Yurisprudensi HR. 3 Desember 1971, NJ 1972, 137 yang pada prinsipnya tidak dapat dibenarkan, adanya kemungkinan bagi pihak yang setelah mempergunakan segala sarana Hukum yang tersedia, namun tidak berhasil dalam gugatannya, untuk memulai suatu gugatan baru terhadap negara berdasarkan Pasal 1365 B.W. karena hal ini berarti keputusan Hakim yang telah mempunyai kekuatan hukum yang pasti, dijadikan lagi sarana dari pemeriksaan baru.

15 Heri Purwanto, 2016, Upaya Ganti Rugi pada Lembaga Praperadilan Akibat Tidak Sahnya Penangkapan dan Penahanan Pasca Dikeluarkannya PP No. 29 Tahun 2015, Jurnal Media Hukum, Vol. 23, No. 1 (Juni 2016), hlm. 48.

${ }^{16}$ Pasal 1365 BW menegaskan bahwa tiap perbuatan melanggar hukum yang mengakibatkan kerugian kepada orang lain mewajibkan orang yang karena salahnya menimbulkan kerugian, mengganti kerugian tersebut. 
Pandangan J.R. Stellinga ${ }^{17}$ bahwa hakim bebas dalam menjalankan tugasnya, maka tidak terdapat suatu ruang gerak bagi pertanggungan jawab Negara atas tindakan Hakim. Hakim di Amerika Serikat dan Malaysia serta di Pakistan juga diberikan kekebalan hukum dari gugatan ganti rugi dalam menjalankan tugas mulianya sepanjang dilakukan dengan itikad baik ${ }^{18}$.

Berkaitan dengan uraian tersebut di atas, maka pertanyaannya adalah apakah aparat penegak hukum selain hakim dapat pula diberi kebebasan untuk tidak dapat digugat perdata atas perbuatan melanggar hukum karena kekeliruan/kesalahan proses penegakan hukum.

Kekebalan hukum tersebut hanya diberikan kepada hakim, namun tidak terhadap penyelidik, penyidik, dan penuntut umum atas tindakan kekeliruan/kesalahan dalam proses penegakan hukum, bisa saja korban mengajukan gugatan perdata terhadap mereka. Terdapat beberapa putusan pengadilan yang mengabulkan gugatan penggugat terkait dengan tindakan kesalahan dalam proses penegakan hukum. Menurut Natasya Senduk ${ }^{19}$ bahwa khusus bagi pihak ketiga yang dirugikan akibat tindakan penegak hukum dalam proses penanganan perkara pidana, maka terdapat model gugatan dapat berupa gugatan perpajakan, gugatan pesangon perusahaan, gugatan perasuransian, kesehatan.

\section{3) Jalur Hukum Administrasi Negara}

Sebagaimana penulis uraikan sebelumnya bahwa seorang bekas narapidana dapat mengajukan hak rehabilitasi kepada presiden selaku kepala negara sebagaimana telah diatur dalam konstitusi. Mekanisme pengajuan pemenuhan hak rehabilitasi oleh bekas narapidana diajukan oleh bekas narapidana atau ahli warisnya atau kuasa hukumnya kepada presiden. Permohonan hak rehabilitasi diberikan oleh presiden setelah meminta pertimbangan Ketua Mahkamah Agung serta meminta saran dan pendepat kepada Menteri Hukum dan HAM serta Jaksa Agung. Pada tataran implementasi pelaksanaan wewenang presiden tersebut ternyata presiden pernah memberikan rehabilitasi terhadap seorang bekas narapidana yang telah menjalani masa pemidanaan yakni Hasbi Abdullah yang telah menjalani pemidanaan selama 14 tahun melalui Keputusan Presiden Nomor 131 Tahun 1999. Penelusuran penulis kasus yang menjerat Hasbi Abdullah terkait kejahatan politik pada waktu Aceh menuntut kemerdekaan. Pemberian rehabilitasi oleh presiden terhadap bekas narapidana termasuk jarang sekali dilakukan oleh seorang presiden.

Merujuk pada Kepres tersebut menurut penulis rehabilitasi yang menjadi wewenang presiden dapat diajukan oleh seseorang yang telah menjalani pemidanaan (bekas narapidana), namun kemudian baru diketahui bahwa orang tersebut tidak bersalah. Atas keadaan hukum tersebut bekas narapidana tersebut dapat menuntut haknya kepada presiden untuk mendapatkan pemulihan nama baik dan kehormatannya kembali ke keadaan dan kedudukan semula. Keadaan hukum tersebut sekaligus untuk menjawab kekosongan hukum bagi seorang bekas narapidana untuk pemulihan nama baik dan

17 J.R. Stellinga, 1951, Grondtrekken van het Ned. Administratif Recht, W.E.J. Tjeenk Willink, Netherlands, hlm. 318.

${ }^{18}$ H.M Fauzan, Peranan Perma \& Sema Sebagai Pengisi Kekosongan Hukum di Indonesia Menuju Terwujudnya Peradilan yang Agung, Prenada Media, Jakarta, hlm. 441.

${ }^{19}$ Natasya Senduk, 2017, Kajian Yuridis Ganti Rugi dan Rehabilitasi Nama Baik Berdasarkan Kitab Undang-Undang Hukum Acara Pidana, Lex Crime, Vol. IV, No. 9 (November 2019), hlm. 18. 
kehormatannya, jika baru diketahui bahwa bekas narapidana tersebut tidak bersalah atas peristiwa pidana yang terjadi, dimana upaya hukum peninjauan kembali tidak dimungkinkan lagi baik karena SEMA No. 7 Tahun 2014 yang membatasi pengajuan peninjauan kembali hanya 1 (satu) kali, walaupun terkait ini masih menjadi polemik hukum karena putusan Mahkamah Konstitusi Nomor 34/PUU-XI/2013, menurut penulis terpidana yang sudah selesai menjalani pemidanaan, tentunya tertutup ruang untuk mengajukan peninjauan kembali.

Menurut penulis hak rehabilitasi sebagaimana diuraikan di atas merupakan hak korban proses penegakan hukum yang menjadi wewenang presiden untuk diberikan kepada bekas narapidana yang setelah menjalani masa pemidanaan baru diketahui bahwa yang bersangkutan tidak bersalah atas peristiwa pidana yang terjadi sebelumnya.

\section{Ganti Kerugian dan Rehabilitasi Terhadap Korban Tindak Pidana}

Pada kajian dan analisis ini, penulis menguraikan terkait dengan ganti kerugian terhadap korban tindak pidana dalam 3 (tiga) jalur hukum yang dapat digunakan oleh seorang korban tindak pidana, yakni jalur hukum acara pidana, jalur gugatan perdata dan di luar pengadilan. Kemudian dilanjutkan dengan kajian dan analisis terkait dengan rehabilitasi terhadap korban tindak pidana.

\section{a. Jalur Hukum Acara Pidana}

Tuntutan ganti kerugian terhadap korban tindak pidana melalui jalur hukum pidana dalam kajian dan analisis ini, penulis bagi dalam 3 (tiga) cara, yakni melalui mekanisme penggabungan perkara dan melalui mekanisme restitusi dan kompensasi serta melalui mekanisme gugatan perdata. Terkait dengan penggabungan perkara tuntutan ganti kerugian memang penulis sadari bahwa menggunakan hukum acara perdata, namun pada kajian dan analisis ini penulis menempatkannya dalam jalur hukum pidana guna memudahkan penulis dalam melakukan kajian dan analisis.

\section{1) Penggabungan Perkara}

Eksistensi ganti kerugian terhadap korban tindak pidana sebenarnya sudah dikenal dalam hukum acara pidana Indonesia sejak berlakunya KUHAP. Ketentuan yang mengatur terkait dengan ganti kerugian terhadap korban tindak pidana dilakukan melalui penggabungan perkara gugatan ganti kerugian diatur dalam Pasal $98-101$ KUHAP. KUHAP mengenal 2 objek yang bisa dijadikan dasar penggabungan perkara yakni: Pertama penggabungan perkara terhadap suatu peristiwa pidana yang terjadi pada beberapa wilayah hukum pengadilan negeri sebagaimana diatur dalam Pasal 84 ayat (4) KUHAP terhadap beberapa perkara pidana yang satu sama lain ada sangkut pautnya dan dilakukan oleh seorang dalam daerah hukum pelbagai pengadilan negeri, diadili oleh masing-masing pengadilan negeri dengan ketentuan dibuka kemungkinan penggabungan perkara tersebut. Kedua penggabungan perkara gugatan ganti kerugian terhadap perkara pidana yang diatur dalam Pasal 98 sampai dengan Pasal 101 KUHAP dan yang kedua ini menjadi fokus kajian dan analisis penulis.

Penggabungan perkata gugatan ganti kerugian dilakukan apabila terhadap suatu perbuatan yang menjadi dasar dakwaan dalam pemeriksaan perkara pidana menimbulkan kerugian terhadap korban tindak pidana. Permintaan penggabungan perkara oleh korban tindak pidana diajukan paling lambat sebelum penuntut umum mengajukan tuntutan pidana atau paling lambat sebelum hakim menjatuhkan putusan. 
Mekanisme pemeriksaan penggabungan perkara tersebut, khususnya terkait dengan gugatan ganti kerugian dilakukan melalui mekanisme hukum acara perdata.

Menurut penulis realitas penegakan hukum, korban tindak pidana banyak yang belum mengetahui akan haknya tersebut dan aparat penegak hukum juga tidak banyak memberikan informasi terkait dengan hak-hak korban tindak pidana, sehingga gugatan ganti kerugian melalui mekanisme penggabungan perkara jarang dilakukan.

Hasil penelitian Nur Azisa ${ }^{20}$ yakni selama Tahun 2010-2014 hanya terdapat 1 kasus kejahatan harta benda yang diajukan permohonan ganti kerugian melalui mekanisme penggabungan perkara, yakni pada Pengadilan Negeri Pare-Pare dalam tindak pidana penipuan, namun putusan pengadilan menyatakan gugatan tidak dapat diterima. Pertimbangan majelis hakim bahwa kewenangan memeriksa gugatan ganti kerugian bukan diwilayah yurisdiksinya karena yang berwenang untuk memeriksa dan memutus gugatan ganti kerugian adalah pengadilan negeri tempat tinggal atau tempat kediaman tergugat (Pelaku kejahatan) dan benda-benda tidak bergerak yang dimohonkan sita jaminan bukan pada wilayah yurisdiksinya serta gugatan penggabungan perkara hanya meliputi kerugian materil sehingga perhitungan kerugian yang ditambah dengan bunga bank sebesar $12 \%$ yang bersifat immateril sudah memasuki ranah gugatan perdata biasa. Permasalahan tersebut menjadi salah satu hambatan pelaksanaan penggabungan perkara ganti kerugian.

\section{2) Restitusi dan Kompensasi}

Selain ganti kerugian terhadap korban tindak pidana yang diatur dalam KUHAP sebagaimana penulis uraikan di atas, dalam ketentuan peraturan perundang-undangan yang berlaku saat ini, terdapat pula ganti kerugian terhadap korban tindak pidana sebagaimana diatur dalam UU No. 13 Tahun 2006 sebagaimana telah diubah dengan UU No. 31 Tahun 2014 tentang Perlindungan Saksi dan Korban. Ketentuan tersebut mengatur terkait dengan konsep restitusi yang menjadi hak korban tindak pidana atau keluarganya yang diberikan oleh pelaku tindak pidana. Di samping itu, terdapat pula kompensasi yang merupakan hak korban tindak pidana yang diberikan oleh negara kepada korban tindak pidana.

Bentuk kerugian yang dialami korban tindak pidana untuk dapat meminta ganti kerugian adalah kerugian atas kehilangan kekayaan atau penghasilan, dan kerugian yang ditimbulkan akibat penderitaan yang berkaitan langsung sebagai akibat tindak pidana, serta penggantian biaya perawatan medis dan/atau psikologis. Pada prinsipnya semua tindak pidana yang dapat melahirkan kerugian terhadap korban sebagaimana dikemukakan di atas dapat menuntut ganti kerugian terhadap pelaku tindak pidana. Berbeda halnya dengan kompensasi yang diberikan oleh negara hanya terhadap korban tindak pidana pelanggaran HAM yang berat dan tindak pidana terorisme, selain kedua tindak pidana tersebut korban tidak dapat menuntut kompensasi.

Mekanisme permohonan restitusi diajukan oleh korban, keluarga atau kuasanya kepada Lembaga Perlindungan Saksi dan Korban (LPSK) yang dapat diajukan sebelum atau setelah putusan pengadilan berkekuatan hukum tetapi. Permohonan restitusi melalui LPSK sebelum putusan pengadilan berkekuatan hukum tetap permohonan disampaikan kepada penuntut umum untuk disampaikan dalam tuntutannya. Sedangkan permohonan

\footnotetext{
${ }^{20}$ Nur Azisa, 2015, Kompensasi Dan Restitusi Bagi Korban Kejahatan Sebagai Implementasi Prinsip
} Keadilan, Disertasi Program Pascasarjana Universitas Hasanuddin, Makassar, hlm. 248-250. 
restitusi setelah putusan pengadilan berkekuatan hukum tetap disampaikan langsung ke pengadilan untuk mendapatkan penetapan.

Terkait dengan mekanisme dan prosedur permohonan restitusi diatur secara tegas melalui Peraturan Pemerintah No. 7 tahun 2018 sebagaimana telah diubah dengan PP No. 35 tahun 2020 tentang Perubahan atas PP No. 7 tahun 2018 tentang Pemberian Kompensasi, Restitusi, dan Bantuan kepada Saksi dan Korban.

Merujuk pada uraian terkait dengan restitusi tersebut di atas, menurut Nur Azisa ${ }^{21}$ bahwa undang-undang yang mengatur hak restitusi beserta mekanismenya masih bersifat parsial, pembentukannya tidak sesuai dengan asas hukum, sistematika dan logika hukum. Pandangan yang sama dikemukakan oleh Budi Suhariyanto ${ }^{22}$ bahwa pengaturan restitusi dalam beberapa ketentuan peraturan perundang-undangan tersebut memiliki perbedaan dalam memberikan pengertian, ruang lingkup dan mekanisme dari pemberian restitusi bagi korban, sehingga terkadang dianggap saling bertentangan. Begitu juga dengan pandangan Meldy Ance Almendo bahwa perlindungan terhadap korban secara political will di Indonesia baru diwujudkan Tahun 2006 yaitu melalui Undang-Undang Nomor 13 Tahun 2006 tentang Perlindungan Saksi dan Korban, namun undang-undang tersebut masih sangat jauh dari keadilan ${ }^{23}$.

\section{b. Gugatan Perdata}

Selain mekanisme permohonan ganti kerugian terhadap korban tindak pidana, baik melalui penggabungan perkara gugatan ganti kerugian maupun melalui LPSK dalam bentuk restitusi dan kompensasi sebagaimana penulis uraikan di atas, terdapat pula ranah hukum lain yang dapat digunakan oleh korban tindak pidana untuk mengajukan permohonan ganti kerugian kepada pelaku tindak pidana, yakni melalui ranah hukum perdata dalam bentuk gugatan perbuatan melanggar hukum. Bentuk ganti kerugian yang dapat dimohonkan oleh korban tindak pidana dalam bentuk gugatan ganti kerugian adalah kerugian materil dan immateril.

Pada prinsipnya semua tindak pidana yang melahirkan kerugian materil terhadap korban tindak pidana dapat mengajukan gugatan ganti kerugian materil. Berbeda halnya dengan kerugian immateril, ketentuan hukum perdata memberikan pembatasan terkait dengan kerugian immateril sebagaimana diatur dalam Pasal 1370, Pasal 1371, dan Pasal 1372 KUHPerdata bahwa ganti kerugian immtaeril hanya dapat diberikan dalam hal-hal tertentu saja seperti perkara kematian, luka berat dan penghinaan.

\section{c. Jalur di Luar Pengadilan (Keadilan Restoratif)}

Selain ketiga cara yang dapat ditempuh oleh korban tindak pidana untuk mendapatkan ganti kerugian atas kerugian yang ditimbulkan akibat terjadinya tindak pidana tersebut, maka penulis menawarkan bentuk lain yang dapat digunakan oleh korban tindak pidana untuk mendapatkan haknya berupa ganti kerugian, yakni melalui penyelesaian perkara pidana melalui keadilan restoratif (restorative justice).

\footnotetext{
21 Nur Azisa, op-cit, hlm. 379-380.

22 Budi Suhariyanto, 2013, Quo Vadis Perlindungan Hukum Terhadap Korban Melalui Restitusi (Perspektif Filsafat, Teori, Norma dan Praktek Penerapannya), Jurnal Hukum dan Peradilan, (Puslitbang Kumdil MA-RI), Vol. 2 No. 1 (Maret 2013), hlm. 111.

23 Meldy Ance Almendo, 2016, Prinsip Keadilan Dalam Tanggung Jawab Negara Terhadap Korban Tindak Pidana Karena Pelaku Tidak Menjalani Pemidanaan, Jurnal Yuridika Universitas Airlangga, Surabaya, Vol. 31 No 1 (Januari 2016), hlm. 63.
} 
Berbagai regulasi internal aparat penegak hukum telah membuka ruang kepada korban tindak pidana untuk mendapatkan ganti kerugian akibat suatu peristiwa pidana yang menimpah korban tindak pidana, yakni Peraturan Kapolri Nomor 6 Tahun 2019 tentang Penyidikan Tindak Pidana dan Peraturan Jaksa Agung Nomor 15 Tahun 2020 tentang Penghentian Penuntutan Berdasarkan Keadilan Restoratif serta Surat Edaran Kapolri Nomor SE/8/VII/2018 tentang Penerapan Keadilan Restoratif (Restorative Justice) dalam penyelesaian perkara pidana.

Penulis menyadari bahwa penyelesaian perkara pidana melalui mekanisme keadilan restoratif belum diatur dalam undang-undang, selain konsep diversi melalui UU No. 11 Tahun 2012 tentang Sistem Peradilan Pidana Anak dan konsep restitusi dan kompensasi melalui UU No. 31 Tahun 2014 tentang Perlindungan Saksi dan Korban.

Berdasarkan pengaturan internal intitusi penegak hukum tersebut di atas, maka ganti kerugian terhadap korban tindak pidana dipenuhi oleh terlapor/teradu/tersangka/terdakwa melalui upaya perdamaian dengan syarat pembayaran ganti kerugian kepada korban tindak pidana oleh pelaku tindak pidana. Demikian kajian dan analisis terkait dengan ganti kerugian terhadap korban tindak pidana.

Selanjutnya hak rehabilitasi terhadap korban tindak pidana menurut penulis belum mendapatkan perhatian serius dari negara, karena pengaturan terkait dengan hak rehabilitasi terhadap korban tindak pidana masih bersifat parsial. Pengaturan terkait dengan hak rehabilitasi terhadap korban tindak pidana hanya diatur melalui undangundang khusus seperti UU. No. 31 Tahun 2014 tentang Perlindungan Saksi dan Korban mengatur terkait dengan hak rehabilitasi terhadap korban tindak pidana.

Pengaturan hak rehabilitasi terhadap korban tindak pidana dalam undang-undang perlindungan saksi dan korban tersebut di atas sangat terbatas hanya korban tindak pidana tertentu saja yang berhak untuk mendapatkan rehabilitasi, yakni:
a. korban tindak pidana pelanggaran HAM yang berat ${ }^{24}$.
b. korban tindak pidana terorisme ${ }^{25}$.
c. korban tindak pidana perdagangan orang ${ }^{26}$.
d. korban tindak pidana penyiksaan.
e. korban tindak pidana kekerasan seksual.
f. Korban tindak pidana penganiayaan berat.

\footnotetext{
${ }^{24}$ Pasal 35 ayat (1) dan ayat (2) UU No. 26 Tahun 2000 tentang Pengadilan HAM memberikan penegasan terkait hak rehabilitasi terhadap korban pelanggaran HAM yang berat atau ahliwarisnya di harus dicantumkan dalam amar putusan pengadilan HAM.

25 Pasal 35A UU No. 5 Tahun 2018 tentang Perubahan atas UU No. 15 Tahun 2003 Tentang Penetapan Peraturan Pemerintah Pengganti Undang-Undang Nomor 1 Tahun 2002 Tentang Pemberantasan Tindak Pidana Terorisme, Menjadi Undang-Undang, memberikan penegasan terkait hak rehabilitasi psikososial dan rehabilitasi psikologis merupakan tanggungjawab negara terhadap korban tindak pidana terorisme, baik korban langsung maupun korban tidak langsung.

26 Pasal 51-52 UU No. 21 Tahun 2007 tentang Pemberantasan Tindak Pidana Perdagangan Orang memberikan penegasan terkait dengan bentuk rehabilitasi terhadap korban tindak pidana perdagangan orang, yakni rehabilitasi kesehatan dan rehabilitasi sosial. Tuntutan hak rehabilitasi diajukan oleh korban atau keluarga korban, teman korban, kepolisian, relawan pendamping, atau pekerja sosial setelah korban melaporkan kasus yang dialaminya atau pihak lain melaporkannya kepada Kepolisian Negara Republik Indonesia dan diajukan kepada pemerintah melalui menteri atau instansi yang menangani masalah-masalah kesehatan dan sosial di daerah. Dalan jangka waktu 7 hari sejak permohonan diajukan wajib diberikan rehabilitasi.
} 
Bentuk konkret dari hak rehabilitasi yang dimaksud di atas adalah rehabilitasi prikososial dan rehabilitasi psikologis. Permohonan rehabilitasi tersebut diajukan kepada LPSK. Uraian terkait dengan hak rehabilitasi terhadap korban tindak pidana belum mendapatkan perhatian serius dari negara sebagaimana penulis kemukakan sebelumnya, karena sampai saat ini belum ada pengaturan khusus terkait dengan hak rehabilitasi terhadap korban keseluruhan tindak pidana. Pertanyaannya apakah korban semua tindak pidana memerlukan rehabilitasi, menurut penulis rehabilitasi merupakan hak korban, hal tersebut penulis dasarkan pada berbagai peraturan perundang-undangan yang ketika menyebut rehabilitasi selalu ditafsirkan sebagai hak korban, baik itu korban proses penegakan hukum maupun korban tindak pidana.

Apabila interpretasi rehabilitasi sebagai hak korban, maka tentunya harus diletakkan secara seimbang terhadap korban dalam hal ini semua korban tindak pidana. Mengingat kedudukan rehabilitasi sebagai hak, maka diletakkan pada pemangku hak apakah akan menuntut penemuhan hak tersebut atau tidak, oleh karena itu yang dilakukan oleh negara adalah menyiapkan perangkat hukum yang memungkinkan semua korban tindak pidana untuk dapat menuntut pemenuhan hak rehabilitasi tersebut.

Mengingat pentingnya pemenuhan hak rehabilitasi terhadap korban tindak pidana, maka menurut penulis mengingat ketentuan peraturan perundang-undangan yang mengatur terkait dengan hak rehabilitasi terhadap korban tindak pidana masih bersifat parsial dan tidak semua korban tindak pidana dapat menuntut pemenuhan hak rehabilitasi, maka permohonan rehabilitasi terhadap korban tindak pidana dapat diajukan bersamaan dengan gugatan ganti kerugian melalui jalur hukum acara perdata.

\section{SIMPULAN}

Ganti kerugian dan rehabilitasi terhadap korban proses penegakan hukum sudah diatur dalam hukum acara pidana Indonesia. Ganti kerugian dan rehabilitasi dapat diajukan oleh tersangka, terdakwa, atau terpidana atau ahli warisnya atau kuasanya baik melalui permohonan praperadilan atau tuntutan tersendiri maupun melalui gugatan perdata atas kekeliruan/kesalahan aparat penegak hukum dalam melaksanakan penegakan hukum terutama tindakan upaya paksa, seperti penangkapan, penahanan, penggeledahan dan penyitaan. Ganti kerugian terhadap korban tindak pidana dapat mengajukan tuntutan ganti kerugian dan rehabilitasi melalui penggabungan perkara dan gugatan perdata terkait perbuatan melanggar/melawan hukum serta permohonan restitusi dan kompensasi melalui LPKS maupun melalui mekanisme keadilan restoratif (restorative justice). Mengingat jumlah ganti kerugian terhadap korban proses penegakan hukum dan korban tindak pidana melalui jalur hukum acara pidana yang diatur dalam ketentuan peraturan perundang-undangan masih relatif kecil dan bersifat parsial, maka diperlukan gugatan perdata melalui perbuatan melanggar/melawan hukum, sehingga dapat menuntut kerugian materil dan immateril. Selain itu guna mendapatkan keadilan yang baik dalam hal ganti kerugian bagi korban oleh pelaku tindak pidana maka penyelesaian melalui mekanisme keadilan restoratif (restorative justice) adalah solusi terbaik.

Hak rehabilitasi terhadap korban tindak pidana hanya korban tindak pidana pelanggaran HAM yang berat, terorisme, perdagangan orang, kekerasan seksual, penganiayaan berat, dan penyiksaan serta korban penyalagunaan narkotika dan psikotropika (pecandu dan penyalah guna). Bentuk rehabilitasi yang diberikan korban tindak pidana tersebut adalah rehabilitasi psikososial, psikologis, kesahatan/medis. Pemenuhan hak rehabilitasi terhadap korban proses penegakan hukum dan korban tindak pidana masih belum 
memadai dan parsial diatur dalam ketentuan peraturan perundang-undangan, oleh karena itu khusus terhadap korban tindak pidana diperlukan pengaturan khusus, sehingga semua korban tindak pidana berhak mendapatkan rehabilitasi. Untuk saat ini ditengah kekosongan hukum pemenuhan rehabilitasi yang ada melalui jalur hukum acara pidana, maka tuntutan pemenuhan hak rehabilitasi terhadap korban tindak pidana dapat dilakukan melalui gugatan perdata bersamaan dengan gugatan ganti kerugian.

\section{DAFTAR PUSTAKA}

Adami Chazawi, 2010, Lembaga Peninjauan Kembali (PK) Perkara Pidana, Sinar Grafika, Jakarta.

Budi Suhariyanto, 2013, Quo Vadis Perlindungan Hukum Terhadap Korban Melalui Restitusi (Perspektif Filsafat, Teori, Norma dan Praktek Penerapannya), Jurnal Hukum dan Peradilan, (Puslitbang Kumdil MA-RI), Vol. 2 No. 1 (Maret 2013).

Erin C. Blondel, 2008, Victims' Rights in An Adversary System, Duke Law Journal, Vol. 58, No. 2 (2008).

Francis D. Boateng dan Gassan Abess, 2017, Victims' Role in The Criminal Justice System: A Statutory Analysis of Victims' Rights in U.S., International Journal of Police Science \& Management, XX (X) (2008).

J.R. Stellinga, 1951, Grondtrekken van het Ned. Administratif Recht, W.E.J. Tjeenk Willink, Netherlands.

Haeranah, 2016, Ganti Kerugian bagi Tersangka, Terdakwa, Terpidana dalam Perspektif Hak Asasi dan Tanggung Jawab Negara, Cet. Kesatu, Pustaka Pena Press, Makassar.

Heri Purwanto, 2016, Upaya Ganti Rugi pada Lembaga Praperadilan Akibat Tidak Sahnya Penangkapan dan Penahanan Pasca Dikeluarkannya PP No. 29 Tahun 2015, Jurnal Media Hukum, Vol. 23, No. 1 (Juni 2016)

H.M Fauzan, Peranan Perma \& Sema Sebagai Pengisi Kekosongan Hukum di Indonesia Menuju Terwujudnya Peradilan yang Agung, Prenada Media, Jakarta.

Kwadwo Ofori-Dua dan Nachinaab John Onzaberigu serta Richard Kofi Nimako, 2019, Victims, the Forgotten Party in the Criminal Justices System: The Perception and Experiences of Crime Victims in Kumasi Metropolis in Ghana, Journal of Victimology and Victim Justice, Vol. 2 No. 2 (2019).

Martiman Prodjohamidjojo, 1989, Pembahasan Hukum Acara Pidana dalam Teori dan Praktek, Pradnya Paramita, Jakarta.

Meldy Ance Almendo, 2016, Prinsip Keadilan Dalam Tanggung Jawab Negara Terhadap Korban Tindak Pidana Karena Pelaku Tidak Menjalani Pemidanaan, Jurnal Yuridika Universitas Airlangga, Surabaya, Vol. 31 No 1 (Januari 2016). 
Natasya Senduk, 2017, Kajian Yuridis Ganti Rugi dan Rehabilitasi Nama Baik Berdasarkan Kitab Undang-Undang Hukum Acara Pidana, Lex Crime, Vol. IV, No. 9 (November 2019).

Nur Azisa, 2015, Kompensasi Dan Restitusi Bagi Korban Kejahatan Sebagai Implementasi Prinsip Keadilan, Disertasi Program Pascasarjana Universitas Hasanuddin, Makassar.

Syarif Abdul Rohma dan Umi Rozah, 2020, Kebijakan Kriminal Mengenai Pemberian Ganti Kerugian Terhadap Korban Salah Tangkap, Jurnal Pembangunan Hukum Indonesia, Vol. 2 No. 1. 